\title{
Research on Tourist Perception of Bama Longevity Village Image Based on Network Text Analysis

\author{
Wei $\mathrm{Li}^{*}$
}

School of Management, Jinan University, Guangzhou, China

DOI: $10.36347 / \mathrm{sjebm} .2020 . \mathrm{v} 07 \mathrm{i} 03.004$

| Received: 16.03.2020 | Accepted: 23.03.2020 | Published: 24.03.2020

*Corresponding author: Wei Li

Abstract

Review Article

The perceived image of tourism destination has a very important influence on the travel choices of potential tourists. Based on the network text analysis, this paper selects travel notes and comments from famous websites such as Ctrip.com and Mafengwo.cn as raw materials, takes Bama Longevity Village as a case, uses ROST CM6.0 software to extract high-frequency vocabulary of network text and carried out emotional analysis to study the tourism destination image of Longevity Village from the perspective of tourists' perception. The results show that, the high-quality natural environment of Longevity Village is deeply loved by tourists, the development and construction are not standardized and infrastructure is lacking however; Tourists' emotional evaluation of Longevity Village is mainly positive emotion, while negative emotion is relatively less. Finally, combined with the conclusion of this study, optimization suggestions are put forward.

Keywords network text; tourism destination image; Bama Longevity Village.

Copyright @ 2020: This is an open-access article distributed under the terms of the Creative Commons Attribution license which permits unrestricted use, distribution, and reproduction in any medium for non-commercial use (NonCommercial, or CC-BY-NC) provided the original author and source are credited.

\section{INTRODUCTION}

Since 1970s, the perceived image of tourism destination has been one of the hot topics studied by scholars at home and abroad. Tourism destination image plays a vital role in tourism decision-making, and potential tourists usually make choices based on other tourists' perception image of the destination [1]. Since Hunt published the study "Image - A Factor in Tourism" in 1971 to discuss the significance of tourism destination image and image factors to tourism destination development, the research on the image of tourism destination has arisen internationally [2]. Subsequently, domestic scholars have gradually turned their attention to the study of tourism destination image. Paying close attention to tourist perception of destination image can understand tourists' sense of identity and satisfaction better, which is profound to the sustainable development of tourism destination.

In recent years, with the rapid development of scientific technology and economy, the Internet is wildly popular among the masses, which has increased the opportunities for tourists to evaluate destinations online. More and more tourists are willing to share their travel experiences and experiences online. Due to the advanced Internet technology, network texts are open, free and sharing, which can reflect the cognition and feelings of tourists perception image of tourism destination intuitively and fully [3]. Therefore, network texts can provide data source for tourism research, and has become one of the main means for domestic and foreign scholars to analyze tourism destinations' image.

\section{LITERATURE REVIEW}

At present, there are many names for the definition of tourism destination image in academic circles, but has not reached a consensus. Tourism destination image, tourist perception image and tourism image are most commonly used, and they are all defined from the perspective of tourists' psychological activities [4]. No matter which name is adopted, the essence is the same. According to Baloglu and McCleary [5], the perceived image of tourism destination can be divided into pre-tourism image and post-tourism image perception on the basis of time division of tourism events. Compared with the perceived image before tourism, the evaluation made by tourists after tourism is more instructive to the development and improvement of the destination. Therefore, the perceived image in this paper refers to the tourist perception of the tourism destination image after traveling.

Foreign studies on tourism destination image started earlier, dating back to the $1960 \mathrm{~s}$, and has achieved many research results. Barich and Kotler [6] 
believed that the image of a tourism destination can be divided into "projection image" and "acceptance image". The projection image is designed and publicized by the government, and the acceptance image is the perceived image. Gartner [7] proposed to divide it from the perspective of tourists' observation, mainly including cognitive image, emotional image and conative image. In terms of influencing factors, studies found that tourists' travel motivation, feeling of service quality, experience, satisfaction and demographic statistical characteristics all affect perceived image of tourism destination [8-10]. Domestic research on tourism image started relatively late. Through sorting out the domestic literature, it was found that the first scholar to work on this research was Li [11]. She mentioned that in the process of urban tourism development, the core competitiveness was the construction of tourism image. And it was necessary to meet the demand of tourists by creating highly recognized, clear and attractive tourism image. Guo [12] combed and analyzed the relevant literature on domestic tourism image perception research, and conducted discussion detailedly from the aspects of research contents, research methods, research areas and research results. Based on Baloglu and McCleary's destination tourism image model, Ganlu [13] investigated domestic tourists to Tibet to analyze the perceived image of Tibet, and obtained the relationship among the three images (namely, cognitive image, emotional image and overall image) which constitute Tibet's tourism image [13]. In addition, Liu, Ma, Li, Niu, and Wei [14] used questionnaire survey to summarize the five influencing factors for evaluating the urban tourism image, including tourism facilities, tourism environment, tourism atmosphere, tourism price and tourism service.

With the advent of big data and information era, domestic and foreign scholars have begun to combine content analysis method with network text data to analyze problems related to tourism image perception. For example, Go and Govers [15] believed that network information played an important role in the formation of tourism destination image. Stepchenkova and Morrison [16] explored Russia's tourism image through tourism websites of the United States and Russia. Choi, Koo, and Choi [17] studied the tourism image of Macao through online reviews and came to the conclusion that differences from online information presented by different tourism organizations would change the image of the same tourism destination. Gao, Zhang, and Zhuang [18] discussed the perceived image of four domestic coastal tourism cities based on online strategies and travel notes from Ctrip.com. Zhang, Li, and Zhang [19] collected tourists' online logs and comments on Huashan to study tourists' perception image of Huashan scenic spot. Guo, Wang, Zhang, and Li [20], Zhang and Luo [21], Zhong, Wu, Wang, and $\mathrm{Mu}$ [22] also collected data on the Internet and made a series of researches on major tourism destinations image perception by text analysis. At the same time, some scholars combined the questionnaire survey and network text to conduct studies [23, 24].

To sum up, the current researches on the perceived tourism image at home and abroad mainly focus on the definition, influencing factors, components, etc. Foreign research work has been carried out earlier and more in-depth than that in China, and the research method is also relatively mature. In contrast, the research on the image of a specific tourism destination occupies a large proportion in the current domestic research, and is usually based on the analysis of the local unique material and cultural resources. Subsequently, the image communication strategy was put forward in a targeted way. In terms of research methods, quantitative analysis and the method of combining quantitative and qualitative analysis have gradually attracted the attention of domestic researchers, but they are relatively deficient. The combination of Internet media and text analysis has become a major trend in the study of tourism destination image, and its theory and feasibility are maturing day by day. It has certain application value in understanding tourism destinations comprehensively and in details. Also, it helps to make development proposals. Based on this, this paper adopts the network text analysis method to explore the tourists' perception and emotional tendency of Bama Longevity Village Image, thus providing reference for the construction and better development of Longevity Village.

\section{METHOD}

\section{Case overview}

Bama is located in Guangxi Zhuang Autonomous Region, China. It is famous as the "Land of World Longevity", tourists have come here to explore the secret of longevity. Longevity Village is one of the villages in Bama. It is named because there have been centenarians in the village since ancient times. At present, many health-seeking tourists have come to visit and live in Longevity Village, where they can have leisure and health activities, hoping to prolong their life with "Bama Therapy". In recent years, the health eco-tourism in Longevity Village has been popular with tourists, but the revisiting rate is very low, resulting in the stagnation of tourism development. Therefore, it is necessary to discuss the tourism image of Longevity Village in order to find the solution.

\section{DATA COLLECTION}

According to the popularity and click rate of the network platform, this paper selects the network comments and travel notes from Ctrip.com and Mafengwo.cn. First of all, "Bama" is used as the subject word to search, and then "Bama Longevity Village" is used as the subject word to expand the search scope. The time span of network text screening is from January 2016 to December 2018. A total of 233 valid texts are obtained by excluding comments that are 
irrelevant to the Longevity Village, are repetitive and invalid, only contain pictures or simply introduce scenic spots. The original data of this study are 233 network texts filtered.

\section{Measurements}

ROST CM6.0 software is used to analyze the obtained network text, which was a content mining system software developed by school of information management, Wuhan University. It is widely used as a tool for online text research. Network text analysis belongs to Content Analysis. Content analysis is a social science research method that measures, analyzes and deduces text and other symbols. The research object can be either text, pictures or other symbols [22]. It can convert qualitative documents into quantitative data, and effectively obtain tourists' real and intuitive impression and evaluation of tourist destinations, so it is welcomed by the vast number of researchers [3]. This study analyzes the tourism image of Longevity Village according to the texts obtained from the web. Firstly, the texts are saved as a .txt file that can be recognizable by ROST CM6.0. Then, the text content is segmented before high-frequency vocabulary analysis and emotion analysis are performed.

\section{RESULTS \\ High-frequency words analysis}

In text analysis, word frequency is the number of times a thing is mentioned, representing its importance in the eyes of reviewers. Therefore, statistics on word frequency are helpful to analyze the focus of tourists. Content mining is carried out on the acquired texts through the ROST CM6.0 software, and words with the length of more than 2 are output to obtain high-frequency feature words with the frequency of the top 600. By deleting some landmark and meaningless words, classifying the words, constructing core themes and analyzing categories, the tourists perception image of Longevity Village can be summarized into five themes (Table 1), namely tourism environment and atmosphere, tourism development and construction, tourism elements and facilities, tourist motivation and tourist senses.

Table-1: High-frequency words in Bama Longevity Village network text

\begin{tabular}{|c|c|c|c|c|c|c|c|}
\hline Theme & Category & Sorting & Vocabulary & $\begin{array}{c}\text { Word } \\
\text { frequency }\end{array}$ & Sorting & Vocabulary & $\begin{array}{c}\text { Word } \\
\text { frequency }\end{array}$ \\
\hline \multirow{12}{*}{$\begin{array}{l}\text { tourism } \\
\text { environment and } \\
\text { atmosphere }\end{array}$} & \multirow{9}{*}{$\begin{array}{l}\text { tourism } \\
\text { environment }\end{array}$} & 1 & Panyang River & 29 & 10 & clean water & 5 \\
\hline & & 2 & beautiful scenery & 27 & 11 & original ecology & 5 \\
\hline & & 3 & fresh air & 20 & 12 & ordinary scenery & 5 \\
\hline & & 4 & picturesque scenery & 12 & 13 & flying dust & 5 \\
\hline & & 5 & $\begin{array}{l}\text { dirty, disorderly and } \\
\text { bad }\end{array}$ & 10 & 14 & $\begin{array}{l}\text { green hills and } \\
\text { clear waters }\end{array}$ & 2 \\
\hline & & 6 & harmonious nature & 9 & 15 & Pure Land & 2 \\
\hline & & 7 & $\begin{array}{l}\text { near the mountain } \\
\text { and by the river }\end{array}$ & 6 & 16 & idyllic scenery & 2 \\
\hline & & 8 & spring water & 6 & 17 & no characteristic & 2 \\
\hline & & 9 & negative oxide ion & 5 & & & \\
\hline & \multirow{3}{*}{$\begin{array}{c}\text { local } \\
\text { atmosphere }\end{array}$} & 1 & enthusiasm & 3 & 4 & noisy & 3 \\
\hline & & 2 & quiet & 3 & 5 & $\operatorname{cozy}$ & 2 \\
\hline & & 3 & simple and honest & 3 & 6 & indifferent & 2 \\
\hline \multirow{5}{*}{$\begin{array}{l}\text { tourism } \\
\text { development and } \\
\text { construction }\end{array}$} & \multirow{5}{*}{$\begin{array}{l}\text { development } \\
\text { and } \\
\text { construction }\end{array}$} & 1 & over-commercialized & 36 & 8 & polluted & 4 \\
\hline & & 2 & be destroyed & 7 & 9 & no planning & 3 \\
\hline & & 3 & $\begin{array}{l}\text { build many new } \\
\text { buildings }\end{array}$ & 4 & 10 & developer & 3 \\
\hline & & 4 & unfinished building & 4 & 11 & overexploitaction & 2 \\
\hline & & 5 & high-rise & 4 & 12 & construction site & 2 \\
\hline
\end{tabular}


Wei Li., Sch J Econ Bus Manag, March., 2020; 7(3): 124-130

\begin{tabular}{|c|c|c|c|c|c|c|c|}
\hline & & 6 & building being built & 4 & 13 & small shop & 2 \\
\hline & & 7 & small booth & 4 & & & \\
\hline \multirow{17}{*}{$\begin{array}{l}\text { tourism elements } \\
\text { and facilities }\end{array}$} & \multirow{6}{*}{ people } & 1 & the aged(103) & 103 & 7 & villager & 10 \\
\hline & & 2 & centenarian & 58 & 8 & $\begin{array}{l}\text { people from out of } \\
\text { village }\end{array}$ & 9 \\
\hline & & 3 & tourist & 37 & 9 & tour group & 6 \\
\hline & & 4 & the longevous & 25 & 10 & package tour & 6 \\
\hline & & 5 & migratory-bird elder & 17 & 11 & package tour & 2 \\
\hline & & 6 & local resident & 15 & 12 & pedlar & 2 \\
\hline & \multirow{3}{*}{$\begin{array}{l}\text { accommodati } \\
\text { on }\end{array}$} & 1 & hotel & 5 & 4 & apartment & 2 \\
\hline & & 2 & guesthouse & 4 & 5 & health institution & 2 \\
\hline & & 3 & agritainment & 2 & & & \\
\hline & \multirow{4}{*}{$\begin{array}{l}\text { food and } \\
\text { beverage }\end{array}$} & 1 & delicious & 16 & 5 & fried fish & 4 \\
\hline & & 2 & local speciality & 11 & 6 & cereal & 4 \\
\hline & & 3 & Bama miniature pig & 9 & 7 & corn flour & 2 \\
\hline & & 4 & Bama miniature pig & 7 & 8 & corn congee & 2 \\
\hline & \multirow{3}{*}{ expenses } & 1 & extra charge & 48 & 4 & free admission & 3 \\
\hline & & 2 & parking fee & 10 & 5 & charge for toilet & 2 \\
\hline & & 3 & free & 4 & 6 & & \\
\hline & $\begin{array}{c}\text { tourism } \\
\text { facilities }\end{array}$ & 1 & cannot find the toilet & 3 & 2 & facilities & 3 \\
\hline \multirow{2}{*}{ tourist motivation } & \multirow{2}{*}{$\begin{array}{l}\text { traveling } \\
\text { motivation }\end{array}$} & 1 & longevity and health & 18 & 3 & prolong life & 2 \\
\hline & & 2 & rehabilitation & 4 & & & \\
\hline \multirow{4}{*}{ tourist senses } & \multirow{4}{*}{ tourist senses } & 1 & regretful & 9 & 5 & attracted & 5 \\
\hline & & 2 & famous & 6 & 6 & uncomfortable & 3 \\
\hline & & 3 & disappointed & 6 & 7 & nice place & 2 \\
\hline & & 4 & wonderful place & 5 & 8 & not worth visiting & 2 \\
\hline
\end{tabular}

\section{Tourism environment and atmosphere}

Among the tourists' comments on Bama Longevity Village, the most mentioned are "Panyang River", "fresh air" and "beautiful scenery". It can be seen that tourists hold a positive attitude towards the original ecological natural environment of the village, and the air and landscape are deeply loved by tourists. The comfortable climate, fresh air and pure water of Longevity Village provide a good living environment for residents. The village has become a residential resort for tourists to come for leisure and health care, which is exactly consistent with the tourists' motivation of "longevity and health" and "recuperation". After visiting and living in Longevity village, most tourists believe that the local folk customs are enthusiastic, simple, quiet and peaceful, "it is a good place for people to get away from the hustle and bustle of the city and return to nature". However, some tourists think that the service attitude is indifferent, and there is a phenomenon of "peddlers racketeering and beating tourists". It can be seen that the local tourism management is still nonstandard and unreasonable. Even a few bad tourism events will greatly reduce the tourists' consumption experience and damage destination image.

\section{Tourism development and construction}


Tourists have more comments on the development and construction of the Longevity Village, second only to peisonel and the tourism environment, and they hold strong negative views on the tourism development of the whole village. "Overcommercialization", "large-scale construction", "overdevelopment" and "no planning" all indicate that the tourism development of Longevity Village ignores protecting the environment. Tourists from other provinces, especially those who come to Bama for seasonal living and health care, usually choose to live in houses built by local villagers. In order to obtain huge economic benefits, villagers scramble to build houses that can be rented by tourists. "The original farmhouse has now turned into brick buildings with 4-5 floors, losing its characteristics." Due to the lack of detailed and comprehensive planning of housing construction and weak awareness of environmental protection, a lot of garbage is piled up on the riverbank, which is not cleaned up in time, leading to a dirty and messy village. Furthermore, it damages the original ecological natural environment seriously and even polluts the high-quality water source in the long run. Building also produces noise pollution, making quiet villages noisy.

\section{Tourism elements and facilities}

It mainly involves personnel, accommodation, food and beverage, expenses and supporting facilities. "The elderly", "longevity elderly" and "centenarians" are the characteristic groups of the local villagers in Longevity Village. The elderly here are healthy and long-lived with high quality of life. They are able to take care of themselves and do some manual work within their capabilities, such as collecting herbs in the mountains, selling commodities and working in fields. Among the tourists, there is a special group called "migratory-bird elders", who live in Longevity Village for a long time seasonally. Some of them come from the northeast to escape the cold winter, and others come for health care. In terms of accommodation, there are family hotels and health-care apartments in the village, which can provide short-term and long-term rental at moderate prices. Tourists can buy and cook their own food to experience the local lifestyle and get involved. Speaking of specialty food, roasted fragrant pig is a special delicacy in the village, which has won unanimous praise from the majority of tourists. The local old people's diets are pure natural ingredients, mainly corn and coarse cereals with little salt. It should be noted that the construction of basic tourism facilities has been neglected in Longevity Village. "Toilet is unavailable", "parking spaces are difficult to find" is the most frequent in tourists' evaluation. The basic needs of tourists have not been met, and their satisfaction has been greatly reduced.

\section{Tourist senses}

Tourists' experience in Longevity Village can be divided into two situations. On the one hand, tourists think the village is a good place worth visiting because of its beautiful scenery. On the other hand, tourists believe that Longevity Village has been destroyed, "feeling uncomfortable, disappointed and regretful". Since the time span chosen for this review is three years, we can make the following assumptions: when Longevity Village was first developed, the environment had not been damaged, the housing construction project had just started, the folk customs were friendly, and tourists were very satisfied. With the development of tourism, the exploiting power has gradually increased; the ecological environment has begun to deteriorate. In addition, the poor management and lack of planning aggravated the tourists' bad tourism experience, and tourists made low evaluation. Therefore, it is particularly important to inspect the tourism image of Longevity Village and implement countermeasures as soon as possible.

\section{Emotion analysis}

Tourists' satisfaction and loyalty often depend on their feelings towards the destination. At present, there are two commonly used emotional classifications in academic circles, namely Binary classification and Ternary classification. Binary classification refers to positive emotion and negative emotion, and Ternary classification refers to positive emotion, neutral emotion and negative emotion. The paper uses the emotion analysis function in ROST CM6.0 software to analyze texts, the results are shown in Table 2, in which positive emotion accounts for $72.53 \%$, far higher than neutral emotion (accounting for 6.44\%) and negative emotion (accounting for $21.03 \%$ ). Judging from the specific situation of each emotion, the positive emotion is dominated by the general level, while the negative emotion is dominated by the general level. Although the positive emotion is the dominant factor in emotion analysis, the negative emotion should not be ignored. According to analysis results of the negative emotion, it can be seen that tourists' negative emotion is caused by excessively strong commercial atmosphere and chaotic phenomenon caused by the excessive development of Longevity Village. Meanwhile, illegal arbitrary charges caused by the chaotic management and ecological destruction are also important reasons for the negative emotion.

Table-2: Emotional tendencies

\begin{tabular}{|c|c|c|}
\hline Emotional type & Number & Proportion (\%) \\
\hline Positive emotion & 169 & 72.53 \\
\hline General & 66 & 28.33 \\
\hline Medium & 53 & 22.75 \\
\hline High & 50 & 21.46 \\
\hline
\end{tabular}


Wei Li., Sch J Econ Bus Manag, March., 2020; 7(3): 124-130

\begin{tabular}{|c|c|c|}
\hline Neutral emotion & 15 & 6.44 \\
\hline Negative emotion & 49 & 21.03 \\
\hline General & 27 & 11.59 \\
\hline Medium & 12 & 5.15 \\
\hline High & 5 & 2.15 \\
\hline
\end{tabular}

\section{CONCLUSIONS}

Taking Bama Longevity Village as an example, this paper uses ROST CM6.0 software to make a high-frequency word analysis of the online texts from Ctrip.com and Mafengwo.cn. It summarizes tourists' perception image of Longevity Village from five themes, including tourism environment and atmosphere, tourism development and construction, tourism elements and facilities, tourism motivation and tourist senses. The results show that tourists hold a positive attitude towards the natural environment and scenery, that is, the original ecological environment with fresh air, beautiful mountains and clear water is attractive to tourists. However, tourism development and construction have led to decrease of tourists' satisfaction, which afffects the tourists' revisiting rate. Then, through the emotional analysis of network data, it is found tourists' positive emotion accounts for $72.53 \%$, the neutral emotion accounts for $6.44 \%$, and the negative emotion accounts for $21.03 \%$, which fully indicates that the satisfaction of tourists is relatively high. However, it can't be ignored that the negative emotion is mainly due to the strong commercial atmosphere and the environmental damage caused by excessive development in Longevity Village.

\section{Managerial implications}

Based on the above research results, it is suggested that Longevity Village shoule be improved in the following aspects in the future for the sustainable tourism development, including making comprehensive planning and developing reasonably; strengthening the protection of the natural ecological environment; improving tourism facilities to meet the needs of tourists.

\section{Making a comprehensive tourism development plan}

The local government should take the initiative to fulfill management responsibilities for Longevity Village, formulate a detailed and thorough plan for tourism development, and advance it in an orderly manner in accordance with the planning strategy. Simultaneously, guidelines will be promulgated and implemented for the construction of tourism facilities, and the illegal buildings will be dealt with seriously. The height of buildings and the distance between buildings and the river should be clearly defined to avoid the destruction of the natural landscape by the building. Besides, it is necessary to strengthen the training of management and service personnel to improve the overall quality of tourism practitioners.

Attaching great importance to the protection of natural environment
According to the results of text analysis, highquality natural environment is the main attraction of Longevity Village and also the advantageous tourism resource of Bama, so it is of great importance to protect the environment. First, we should vigorously carry out environmental protection education and publicity work; fundamentally strengthen the awareness of environmental protection among tour operators, tourists and local villagers, so as to guide them to consciously protect the local environment. Second, it is critical to strengthen the improvement and management of environmental sanitation in the village. We need solve the problems of garbage cleaning, recycling and reuse, sewage discharge treatment, daily cleaning and so on, especially the protection of Panyang River.

\section{Establishing and improving tourism infrastructure}

Problems such as serious shortage of tourism infrastructure and public service facilities, nonstandard construction will lead to poor tourism environment, which affect tourists' experience quality. Therefore, the diversified needs of tourists should be met in terms of accommodation, catering, health environment and leisure facilities. By increasing the supply of public service facilities, such as strengthening the construction of tourist toilets, tourist signage system and public rest places in scenic spots, we can provide considerate and thoughtful services for tourists. Moreover, long-term occupants of "migratory-bird elders" are mostly the elderly who come from other places, so a wellfunctioning medical and health service system is vital to them.

\section{REFERENCES}

1. Fakeye PC, Crompton JL. Image differences between prospective, first-time, and repeat visitors to the Lower Rio Grande Valley. Journal of travel research. 1991 Oct; 30(2):10-6.

2. Song, B. H., Ma, Y. F., Gao, N., Liu, J. S., \& Liu, Z. X. (2016). A study on TDI perception based on web text-An impirical analysis of Pingyao ancient city. Journal of Arid Land Resources and Environment, 30(03), 202-208.

3. ZHANG Y. Study on rural tourism image perception based on content analysis of travelers' web text: taking Zhujiayu of Jinan as a case. Journal of Fujian Agriculture and Forestry University,(2). 2016:65-70.

4. SU LJ, HUANG FC. An Empirical Study on the Influencing Factors of Tourist Perceived Image and Their Effect on Tourist Loyalty [J]. Journal of Business Economics. 2010;6.

5. McCleary KW. A model of destination image formation. Annals of Tourism Research. 
1999;26(4):868-97.

6. Barich H, Kotler P. A framework for marketing image management. MIT Sloan Management Review. 1991;32(2):94.

7. Gartner WC. Image formation process. Journal of travel \& tourism marketing. 1994 Feb 9;2(23):191-216.

8. Woodside AG, Lysonski S. A general model of traveler destination choice. Journal of travel Research. 1989 Apr;27(4):8-14.

9. Goodrich JN. A new approach to image analysis through multidimensional scaling. Journal of travel research. 1978 Jan;16(3):3-7.

10. Beerli A, Martin JD. Factors influencing destination image. Annals of tourism research. 2004 Jul 1;31(3):657-81.

11. Beerli A, Martin JD. Factors influencing destination image. Annals of tourism research. 2004 Jul 1;31(3):657-81.

12. Ying-zhi GU. Summarize on the study results of tourism appreceiving image $[\mathrm{J}]$. Economic Geography. 2003;2.

13. Gan L, Lu T, Wang X. An empirical study of the domestic tourists' perception on Tibet's tourism image. Tourism Science. 2013;27(2):73-82.

14. Li X. Destination Image Perception of Tourists to Guangzhou-Based on Content Analysis of Online Travels. Journal of Service Science and Management. 2015;8(05):662.

15. Go F, Govers R. Projected destination online: Website content analysis of picture and text. Information Technology and Tourism. 2005;7(2):18.

16. Stepchenkova S, Morrison AM. The destination image of Russia: From the online induced perspective. Tourism management. 2006 Oct 1;27(5):943-56.
17. Choi I, Koo M, Choi JA. Individual differences in analytic versus holistic thinking. Personality and Social Psychology Bulletin. 2007 May;33(5):691705.

18. Gao J, Zhang Y, G and Zhuang DQ. A study on domestic tourists' perception image of seaside cities_-Based on text analysis of comments from Ctrip and Tongcheng LY. Consumer Economics.2009; 25(03), 62-65.

19. Zhang GJ, Li JY and Zhang L. A research on tourism destination image perception of Huashan scenic spot: Based on text analysis of weblogs. Tourism Science.2011; 25(04), 87-94.

20. Guo FH, Wang K, Zhang JL, and Li RJ. Rural tourism destination image of the case in "Five Golden Flowers", Chengdu: Based on the text mining of blogs. Tourism Tribune.2015; 30(04), 84-94.

21. Zhang WT and Luo PC. A comparative research on tourism destination image of tourists' perception and official dissemination based on network text- Taking Yongding Tulou in Fujian as the case. Journal of Fujian Normal University (Natural Science Edition).2017; 33(01), 90-98.

22. Zhong $\mathrm{N}, \mathrm{Wu}, \mathrm{XG}$, Wang $\mathrm{X}$ and $\mathrm{Mu} \mathrm{XY}$. Research on difference of Yixing tourism destination image based on web text analysis. Resource Development \& Market.2018; 34(08), 1168-1172.

23. Cheng $\mathrm{P}$ and $\mathrm{Yan} \mathrm{Y}$. The new media tourism micro-blog's attraction for tourists: A case study on network text analysis of Elong Sina micro-blog. Tourism Forum.2012; 5(03), 22-26.

24. Zhang ZZ and Li JN. A comparative study on the data of a questionnaire and web texts in tourism image researches: A case study of Xi'an's tourism image perception. Tourism Science.2014; 28(06), 73-81. 